\title{
Periodisation of the Neolithic and radiocarbon chronology of the Early Neolithic and the beginning of the Middle Neolithic in Finland
}

\author{
Kerkko Nordqvist, Teemu Mökkönen \\ Archaeology, University of Oulu, Oulu, FI \\ kerkko.nordqvist@gmail.com; teemu.mokkonen@gmail.com
}

\begin{abstract}
This paper discusses the basis of Neolithic periodisation used in mainland Finland. It is suggested that the periodisation should be revised: the boundary between the Middle and Late Neolithic periods should be moved to correspond with the appearance of Corded Ware (c. $2800 \mathrm{cal}$ $B C$ ), and the term 'Final Neolithic' introduced to cover the final centuries of the Neolithic. This kind of division would reflect changes in the cultural development better than that currently in use. In addition, the chronological frames for the pottery types dated between the late $6^{\text {th }}$ and mid-4th millennium cal BC, i.e. the Early Neolithic and the beginning of Middle Neolithic, are presented.
\end{abstract}

KEY WORDS - Early Neolithic; Middle Neolithic; periodisation; radiocarbon chronology; Finland

\section{Periodizacija neolitika in radiokarbonska kronologija zgodnjega neolitika in začetka srednjega neolitika na Finskem}

\begin{abstract}
IZVLEČEK - V članku razpravljamo o osnovah periodizacije neolitika na območju celinske Finske. Predlagamo ponoven razmislek o periodizaciji: mejo med srednjim in poznim neolitikom bi morali premakniti tako, da bi ustrezala začetku kulture vrvičaste keramike (ok. 2800 pr. n. št.), in dodati fazo 'finalnega' neolitika, ki bi vključeval poslednja stoletja v obdobju neolitika. Te spremembe bi bolje odsevale spremembe v kulturnem razvoju kot trenutna periodizacija neolitika. Dodatno predstavljamo tudi kronološke okvirje za tipe posod, ki jih datiramo med pozno 6. in srednje 4. tisočletje pr. $n$. št., torej čas zgodnjega in začetka srednjega neolitika.
\end{abstract}

KLJUČNE BESEDE - zgodnji neolitik; srednji neolitik; periodizacija; radiokarbonska kronologija; Finska

\section{Introduction}

The chronological framework of the Neolithic applied in Finland differs from those currently used in neighbouring areas. The deviation does not concern the beginning of Neolithic, but internal division of the period. This paper deals with the basis of the periodisation and presents the chronological frames for pottery types dated between the late $6^{\text {th }}$ and mid- $4^{\text {th }}$ millennium cal BC, i.e. the Early Neolithic (EN; 5200-3900 cal BC) and the beginning of the
Middle Neolithic (MN; 3900-2300 cal BC) in mainland Finland. ${ }^{1}$ No comprehensive list of Finnish radiocarbon dates is included in this article, since most of the EN-MN radiocarbon data originates in the Dating Laboratory of the Finnish Museum of Natural History (Luomus) with lab-codes Hel (conventional) and Hela (AMS); some of these ${ }^{14} \mathrm{C}$ data have been published in the series Radiocarbon Dates (for the latest volume, see Jungner, Sonninen 2004; also e.g.,

1 All datings in this paper is calibrated with OxCal 4.2 (Bronk Ramsey 2009) and the calibration curve IntCal13 (Reimer et al. 2013). 
Carpelan 2004; Pesonen 2004; Pesonen et al. 2012), and the whole dataset should be available in an open-access database in the near future ${ }^{14} \mathrm{CARHU}$, see www.oasisnorth.org). Thus, Appendix 1 includes only the published (AMS) dates made in other laboratories than Helsinki.

\section{Chronology and periodisation}

The beginning of the Neolithic is defined by the appearance of ceramics, and pottery is also the main element for further internal division of the period. The periodisation currently in use is based on Christian Carpelan's (Carpelan 1979) compilation of earlier pottery typology studies and shoreline displacement-based chronologies (see Siiriäinen 1974). Even if the EN-MN division finds support in the general archaeological material, the subsequent periodisation is rather nondescript and does not reflect changes in cultural development. The $\mathrm{MN}$ is seen to continue some 1700 years and contain a variety of different pottery types and cultures, including Typical and Late Comb Ware, asbestos- and organic-tempered wares (Kierikki and Pöljä Wares), and Corded Ware. The Late Neolithic (LN) is often dated to 2300-1800 cal BC and is exemplified in the archaeological record by the coastal Kiukainen Ware in particular.

In north-eastern Europe, the appearance of pottery and the beginning of the Neolithic is generally accepted as taking place $c$. 5500-5200 cal BC (Kriiska, Lang 2001; German 2011; Pesonen et al. 2012; Piezonka 2015). Research on this earliest phase of the Neolithic has been sometimes interregional (e.g., Torvinen 2000; 2004; Hallgren 2008; Piezonka 2015), but after the EN, attempts to overcome national and linguistic borders in east-west direction have been surprisingly few (see Carpelan 1979; Mökkönen 2011; Nordqvist 2013). Interestingly, for example, Typical Comb Ware is recognised as a phenomenon existing in Finland, parts of northwest Russia, Estonia, and Latvia (e.g., Europaeus-Äyräpää 1930; Jaanits et al. 1982; Vitenkova 2002), but still lacks any truly inter-regional studies. While it is true that regional differ- ences in the material culture do exist, the regional periodisations reflect more local research traditions and their emphases than real prehistoric differences between these areas (Fig. 1).

The current periodisation of the EN and the first part of the MN in Finland and Estonia is roughly equal, whereas the practice of placing the line between the MN and the LN is a different story. The deviation between Finnish and Russian periodisations is also notable: the Finnish MN is temporally equivalent to the Russian LN and Eneolithic/the beginning of the Early Metal Period. This is due to the fact that Finnish archaeology operates within a much more limited area than its Russian counterpart, and therefore it is not directly influenced by the research and periodisation of more southern areas (see also Nordqvist 2013).

In the context of north-east European archaeology, the long $\mathrm{MN}$, from $c .3900$ to $2300 \mathrm{cal} \mathrm{BC}$, is a peculiarity of Finnish periodisation. As we pointed out

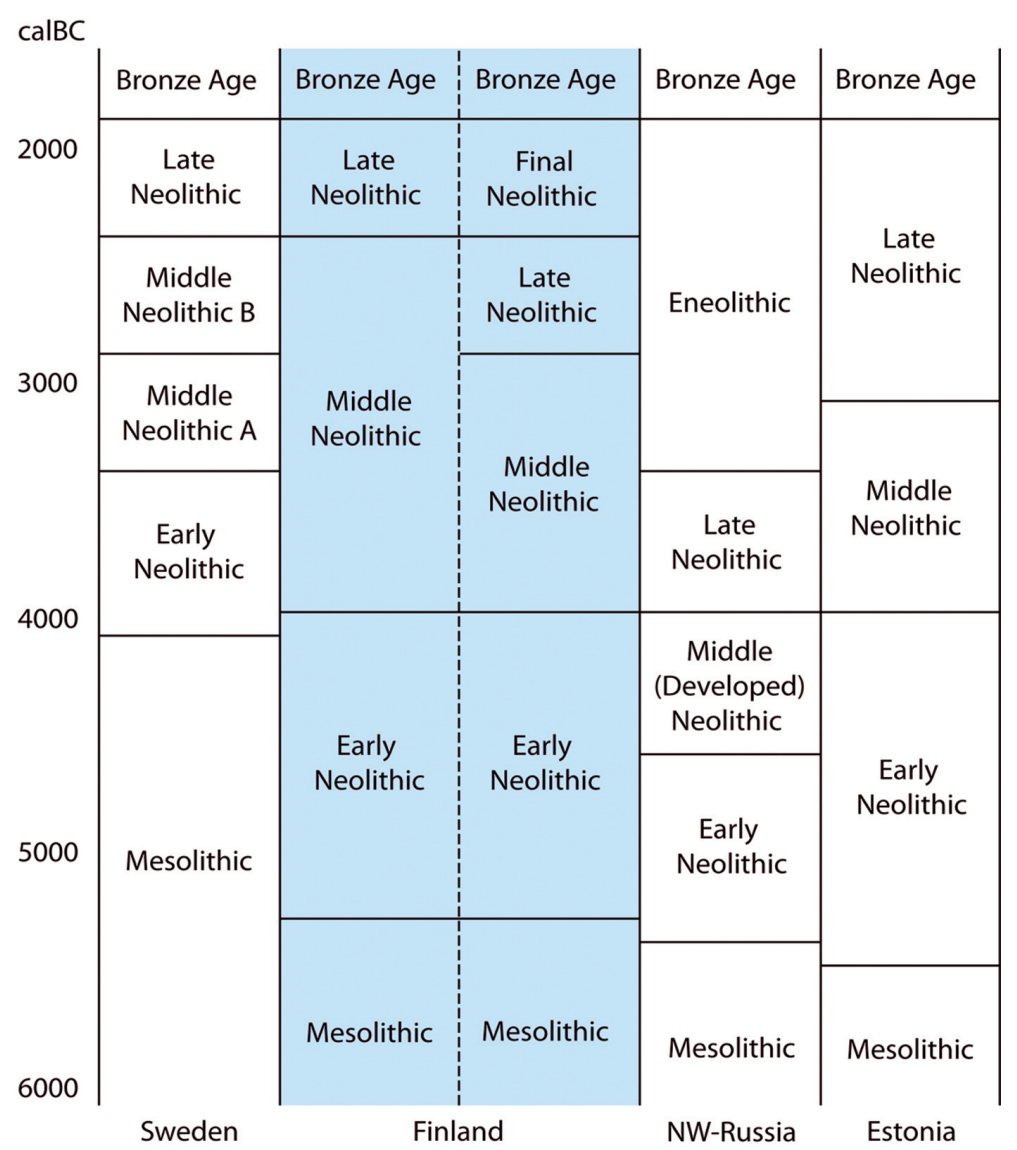

Fig. 1. General periodisations in Finland and neighbouring areas of Sweden (after Hallgren 2008; Larsson 2009), north-west Russia (after Kosmenko, Kochkurkina 1996; Zhul'nikov 1999), and Estonia (after Kriiska, Lang 2001). The figure presents the traditional periodisation used in Finland (see Carpelan 1979; 1999), and the new periodisation suggested here. 
above, this is the product of $20^{\text {th-century pottery }}$ typo-chronologies constructed prior to the application of accurate ${ }^{14} \mathrm{C}$ datings. Since then, the AMS dating technique has changed the temporal coverage of the typologically defined ceramic types (e.g., Pesonen 2004; Pesonen, Leskinen 2011) and, consequently, altered their chronological positions and mutual relations. Due to new datings, Typical Comb Ware is now completely subsumed within the MN (seen even as the boundary for its beginning), whereas it was previously placed partly within the EN and partly the MN (see Carpelan 1979.11, Fig. 2). Apart from this change, the main frame of periodisation has not been revised. The invalid synchronisation between the absolute datings of pottery types and the general periodisation is seen well in a comparison between the chronological charts presented in the 1970s and the 2010s (Carpelan 1979.11, Fig. 2; cf. Mökkönen 2011.17, Fig. 5), modified and reproduced here as Figure 2.

The appearance of the Corded Ware phenomenon in Finland at c. $2800 \mathrm{cal} \mathrm{BC} \mathrm{(Mökkönen} \mathrm{2011;} \mathrm{Nord-}$ qvist 2016) is not visible in the currently used perio- disation, even if it is a chronological boundary in neighbouring areas. In order to jettison the unduly long MN, we suggest a similar chronological division in Finland, and a separation of the current MN into two, into Middle and Late Neolithic. ${ }^{2}$ The term Final Neolithic could be applied to the last centuries of the Neolithic after the decline of Corded Ware at $c$. 23001800 cal BC (i.e. the phase currently called LN).

The revised periodisation for Finland suggested here does not neither correspond neatly with all the phenomena observed in the current archaeological material. Nevertheless, even if Corded Ware is present in southern Finland only, it influences and is coeval with changes taking place in more northern areas, too, and therefore its use as a boundary is justified. Likewise, the separation of the Final Neolithic is based mainly on southern coastal materials, but supporting evidence can be found elsewhere, too. Therefore, the revised periodisation would be more suitable when dealing with wider typo-chronological entities within and beyond the borders of Finland than the chronological frame currently in use, which has become incompatible with present archaeological data.

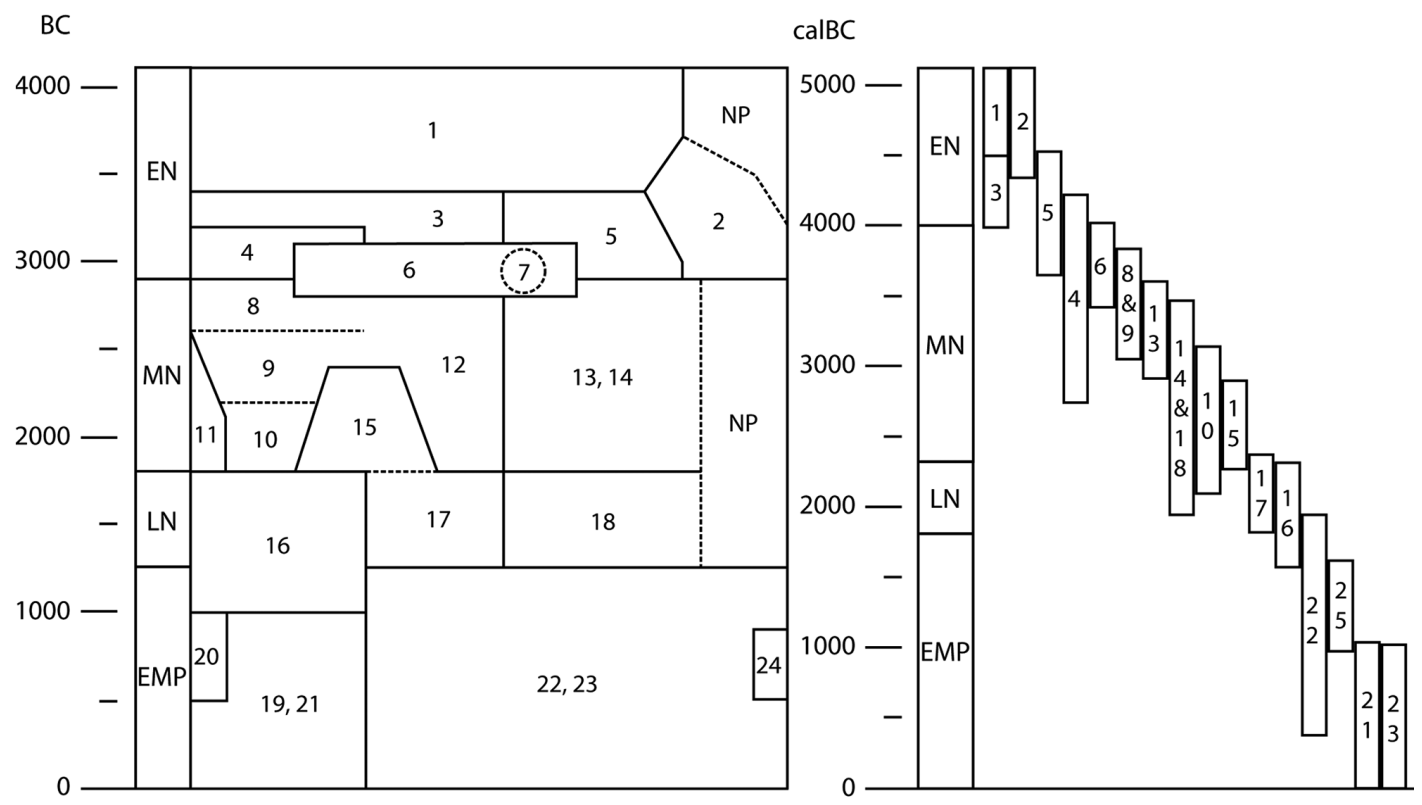

Fig. 2. Chronological charts presented for Finland in the 1970s (left) and the 2010s (right) (modified from Carpelan 1979.11, Fig. 2; Mökkönen 2011.17, Fig. 5). Periods: EN - Early (Sub)Neolithic; MN - Middle (Sub)Neolithic; LN - Late (Sub)Neolithic; EMP - Early Metal Period; Pottery types: 1 Sperrings 1 (Ka I:1); 2 Säräisniemi 1; 3 Sperrings 2 (Ka I:2); 4 Jäkärlä; 5 Early Asbestos Ware; 6 Typical Comb Ware (Ka II); 7 'Russian Pitted Ware' (i.e. Pit-Comb Ware); 8 Uskela (Ka III:1); 9 Sipilänhaka (Ka III:2); 10 Pyheensilta; 11 East-Swedish Pitted Ware; 12 'Late Comb Ware of the Middle Zone'; 13 Kierikki; 14 Pöljä; 15 Corded Ware; 16 Kiukainen; 17 Middle Zone Ceramics; 18 Jysmä; 19 'fine Lausitz-influenced pottery'; 20 Otterböte; 21 Morby etc.; 22 Sarsa-Tomitsa (Textile Ware); 23 Säräisniemi 2; 24 Pseudo Textile Ware; 25 Paimio; NP - no pottery.

2 Recently, some signs of the need to move the MN-LN boundary towards this direction have been seen, although at what point in time it has been placed and why are still varied (see Lavento 2012; Seitsonen et al. 2012; Halinen 2015; Vanhanen, Pesonen 2016). 
Early Neolithic, c. 5200-3900 cal BC

The first ceramics appear in Finland in the form of two types. The southern type, Sperrings 1 Ware (or older Early Comb Ware, style I:1; also known as Ka I:1), occupies most of Finland up to southern Lapland, and the corresponding area in north-west Russia (Map 1A, Fig. 3a-b). The northern type, Säräisniemi 1 Ware (or Sär 1), overlaps with Sperrings 1 in the north and is distributed up to the shore of the Barents Sea (Fig. 3c-e). The definition of Sperrings 1 is based on early research (Europaeus-Äyräpää 1930; also Äyräpää 1956; Luho 1957), and later studies of the type are few in Finland (but see German 2002; 2011 for Russian Karelia). In contrast, the basic research on Säräisniemi 1 was carried out only recently (Torvinen 2000; 2004; Skandfer 2005; 2011). In Finland, Sperrings 1 dates to the earlier part of the EN, from 5300-5200 up to 4500-4400 cal BC (Pesonen, Leskinen 2011; Pesonen et al. 2012; Piezonka 2015; Nordqvist, Mökkönen 2016; 2017a). The use of Säräisniemi 1 starts at the same time, 5300-5200 cal $\mathrm{BC}$, but its final dating is still unclear. Most of the reliable dates are older than $4400 \mathrm{cal} \mathrm{BC}$, although individual dates as young as $3800 \mathrm{cal} \mathrm{BC}$ exist (Torvinen 2000; Skandfer 2005; 2011; Pesonen, Leskinen 2011; Pesonen et al. 2012; Nordqvist, Mökkönen 2016; 2017a).

Around $4500 \mathrm{cal} \mathrm{BC}$, new pottery types enter the scene. Sperrings 2 Ware (or younger Early Comb Ware, style I:2, also Ka I:2) was defined alongside Sperrings 1 (Europaeus-Äyräpää 1930), and, similarly, subsequent research of this pottery type has been very limited (Luho 1957; Rankama 1982) (Fig. 3f). At the same time, the use of local asbestos minerals starts in the inland lake district and results in the emergence of an asbestos-tempered variant of Sperrings 2 Ware (Fig. 3h). Its distribution is mostly confined to Finland and the Karelian Isthmus (Russia) (Map 1B). The end of Sperrings 2 use is dated to c. $4000 \mathrm{cal} \mathrm{BC}$, although the use of an asbestos-tempered variant may have continued for some centuries longer (Pesonen, Leskinen 2011; Pesonen et al. 2012; Nordqvist, Mökkönen 2016).

Another asbestos-tempered early pottery type is called Kaunissaari Ware (Fig. 3g). Its first appearance is dated to $c .4300 \mathrm{cal} \mathrm{BC}$, while production terminates c. 3800 cal BC (Pesonen, Leskinen 2011; Oinonen et al. 2014; Nordqvist, Mökkönen 2016). The distribution of Kaunissaari Ware is centred on the eastern lake area of Finland, but the type is also present in Ostrobothnia. Even though Kaunissaari Ware was recognised already in the early $20^{\text {th }}$ century (Pälsi 1915), the basic research was done only in the 1990s (Pesonen 1996). Asbestos-tempered Sperrings 2 and Kaunissaari Wares have been usually discussed under the common term Early Asbestos Ware (Pesonen 1996), although these two pottery types do not have much common, except the application of asbestos. They are known only in small amounts in western Russian Karelia, where much of the $5^{\text {th }}$ millennium cal BC is characterised by Pit-Comb Ware (see Tarasov et al. 2017).

In coastal south-western Finland, an early ceramic type called Jäkärlä Ware was identified as a local parallel to Sperrings 1 and 2 potteries (Edgren 1966;

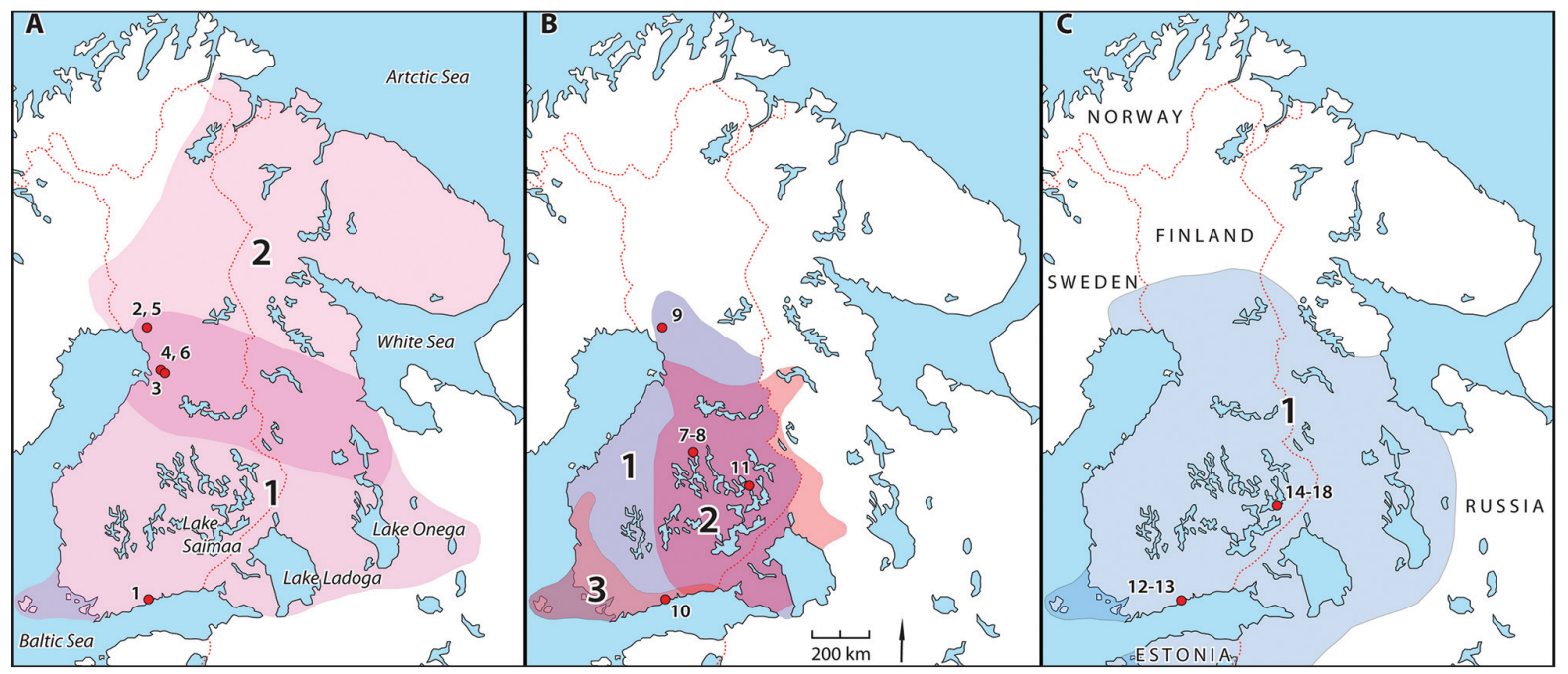

Map 1. A: The first half of the Early Neolithic. 1 - Sperrings 1 Ware; 2 - Säräisniemi 1 Ware. B: The second half of Early Neolithic. 1 - Sperrings 2 Ware; 2 - Asbestos-tempered Sperrings 2 and Kaunissaari Wares; 3 -Jäkärlä Ware. C: Early Middle Neolithic. 1 - Typical Comb Ware. The dots mark the locations of sites with datings 1-18 (see Appendix 1. Map designed by K. Nordqvist). 
1992). Its dating and cultural contextualisation are problematic. Based on shoreline displacement, Jäkärlä Ware is dated roughly to $4300-3000 \mathrm{cal} \mathrm{BC}$ (no AMS dates have been published) and considered as a western variant of Comb Wares (Asplund 1995; 2008; cf. Pesonen, Leskinen 2011). Thus, it seems that after the earliest phase marked by Sperrings 1 and Säräisniemi 1 Wares, Finland divided into four coeval and partly overlapping pottery traditions: Kaunissaari Ware in the east, Sperrings 2 Ware in the southern and central parts of the country, Jäkärlä Ware in south-western Finland, and Säräisniemi 1 Ware in the north, in addition to which Karelian Pit-Comb Ware influence reached eastern Finland.

Early Middle Neolithic, c. 3900-3500 cal BC The EN-MN border is nowadays marked by the appearance of Typical Comb Ware (also Ka II, styles II:1 and II:2), dated to 3900-3400 cal BC (Pesonen 2004; Pesonen, Leskinen 2011; see also Nordqvist, Mökkönen 2017a) (Fig. 3i-j). As the material culture con- nected with Typical Comb Ware is distinctive and archaeologically highly visible, the pottery type was identified already in the early $20^{\text {th }}$ century (Ailio 1909; Pälsi 1915) and more closely defined in the 1920s (Europaeus-Äyräpää 1930). Typical Comb Ware is considered a widely distributed and uniform cultural entity that covers the whole of Finland up to southern Lapland (Map 1C). However, regional variation in decoration, temper and shapes is recognisable, and in the light of now-existing material the original definition is inadequate and generalising and does not acknowledge this diversity (Nordqvist, Mökkönen 2015a; 2015b).

Originally, Typical Comb Ware and Late Comb Ware (also Ka III) were regarded as chronologically subsequent styles (Europaeus-Äyräpää 1930; see also Vikkula 1981). AMS dates, however, revealed that they are partially contemporaneous: Late Comb Ware dates to 3600-3200 cal BC (Pesonen 2004) or even as late as $2800 \mathrm{cal}$ BC (Pesonen, Leskinen 2011; Seitsonen et al. 2012). At the moment, the pottery typologies after Typical Comb Ware are more or less
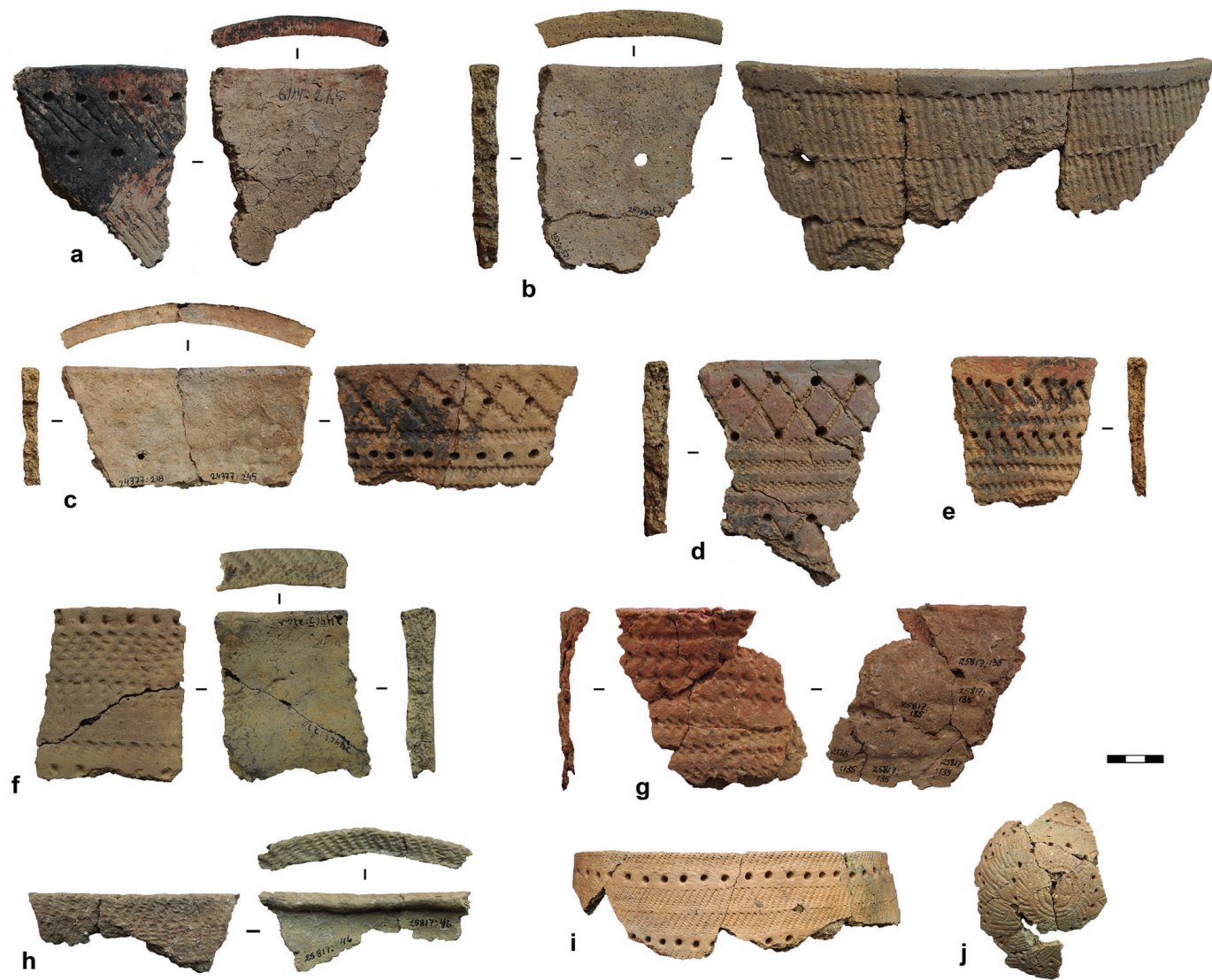

Fig. 3. Early and Middle Neolithic pottery from Finland: a-b Sperrings 1 Ware; c-e Säräisniemi 1 Ware; $f$ Sperrings 2 Ware; $g$ asbestos-tempered Kaunissaari Ware; $h$ asbestos-tempered Sperrings 2 Ware; and i-j Typical Comb Ware. Collection numbers (KM- the National Museum of Finland): a KM 6114:275; b KM 24750:571; c KM 24377:218, 245; d KM 30561:786; e KM 25731:385; f KM 24465:220; g KM 25817: 135; h KM 25817:46; i KM 30319:754; j KM 30319:934. Scale 3cm (photos by T. Mökkönen). 
in a state of confusion (see Mökkönen 2011; Nordqvist 2015). Some EN pottery types overlap with Typical Comb Ware and local traditions remain visible in many places. For example, the use of asbestos temper continues in Typical Comb Ware in the eastern lake district, and from at least $3600 \mathrm{cal} \mathrm{BC}$ onwards, predominately asbestos-tempered pottery types (Kierikki Ware in Finland, Voynavolok Ware in Karelia) become visible again (see Zhul'nikov 1999; Pesonen 2004; Pesonen, Leskinen 2011; Nordqvist, Mökkönen 2017a; 2017b).

\section{Discussion}

Large-scale periodisations, just like pottery types, are always artificial generalisations. Even so, a certain correspondence between the frame and the content (i.e. archaeological material) is required, because otherwise the framework turns from a helpful assistant into a harmful obstacle that misguides research. As archaeological knowledge is accumulated, the validity of this frame should be re-evaluated every so often; this has been neglected in Finland.

The increasing amount of radiocarbon datings has reduced the actual use of traditional periodisation framework. This is reflected in recent overview papers, in which time is divided according to pottery types and their ${ }^{14} \mathrm{C}$ dates, and the phases of Neolithic periodisation are not mentioned at all (see Carpelan 1999; Pesonen, Leskinen 2011), or, if applied, used as abstract terms with no definition of their content (see Pesonen 2004). That is to say, the building of absolute chronologies has replaced the maintenance of general periodisation. Even if these two chronological frames share certain elements, their essential features do not completely overlap: absolute chronologies set, for example, the temporal limits of certain pottery types, while a general periodisation should also incorporate other archaeological knowledge, such as possible changes in subsistence or settlement patterns, other material culture, etc.

In Finland, the basic research on the material culture of several Neolithic phases is at an incomplete stage. At the same time, the growing popularity of research based on the natural sciences has refocused research questions, and periodisation has lost its attraction. Specific answers obtained through technologically-aided research are highly necessary. Nonetheless, a larger framework that takes into account cultural development as a whole is needed to provide the wider context for these results.

\section{ACKNOWLEDGEMENTS}

This paper was produced within the project 'The use of materials and the Neolithisation of north-east Europe (c. 6000-1000 BC)' financed by the Academy of Finland and the University of Oulu (2013-2017, project \#269066).

\section{References}

Ailio J. 1909. Die steinzeitlichen Wohnplatzfunde in Finland: I. Teil: Übersicht der Funde. Finnische Altertumsgesellschaft. Helsingfors.

Asplund H. 1995. Radiocarbon dating of Jäkärlä ceramics: a Comment on Comb ceramic chronology and typology. Karhunhammas 16: 69-75.

2008. Kymittce: Sites, Centrality and Long-term Settlement Change in the Kemiönsaari Region in SW Finland. Annales Universitatis Turkuensis Ser. B Tom. 312. University of Turku. Turku.

Äyräpää A. 1956. Den yngre stenålderns kronologi i Finland och Sverige. Finskt Museum 62(1955): 5-47.
Bronk Ramsey C. 2009. Bayesian analysis of radiocarbon dates. Radiocarbon 51(1): 337-360.

Carpelan C. 1979. Om asbestkeramikens historia i Fennoskandien. Finskt Museum 85(1978): 5-25.

1999. Käännekohtia Suomen esihistoriassa aikavälillä 5100-1000 eKr. In P. Fågelberg (ed.), Pohjan poluilla: Suomalaisten juuret nykytutkimuksen mukaan. Bidrag till kännedom av Finlands natur och folk 153. Finska vetenskaps-societeten. Helsinki: 249-280.

2004. Environment, archaeology and radiocarbon dates: Notes from the Inari region, northern Finnish Lapland. In M. Lavento (ed.), Early in the North: Volume 5: The 
Land. Iskos 13. The Finnish Antiquarian Society. The Archaeological Society of Finland. Helsinki: 17-45.

Edgren T. 1966. Jäkärlä-gruppen: En västfinsk kulturgrupp under yngre stenåldern. Suomen Muinaismuistoyhdistyksen Aikakauskirja 64. The Finnish Antiquarian Society. Helsinki.

1992. Den förhistoriska tiden. In M. Norrback (ed.), Finlands historia 1. Schildts. Esbo: 9-270.

Europaeus-Äyräpää A. 1930. Die relative Chronologie der steinzeitlichen Keramik in Finnland I-II. Acta Archaeologica 1: 165-190, 205-220.

German K. E. 2002. Khronologiya i periodizatsiya kul'tury sperrings v Karelii. Tverskoy arkheologicheskiy sbornik 5(1): 264-273. (in Russian)

2011. Early hunter-gatherer ceramics in Karelia. In P. Jordan, M. Zvelebil (eds.), Ceramics before Farming: the Dispersal of Pottery among Prehistoric Eurasian Hunter-Gatherers. Left Coast Press. Walnut Creek: 255280.

Halinen P. 2015. Kivikausi. In G. Haggrén, P. Halinen, M. Lavento, S. Raninen and A. Wessman, Muinaisuutemme jäljet: Suomen esi-ja varhaishistoria kivikaudelta keskiajalle. Gaudeamus. Helsinki: 17-121.

Hallgren F. 2008. Identitet och praktik: Lokala, regionala och överregionala sociala sammanhang inom nordlig trättbägarkultur. Coast to Coast books 17 . University of Uppsala. Uppsala.

Jaanits L., Laul S., Lõugas V. and Tõnisson E. 1982. Eesti esiajalugu. Eesti raamat. Tallinn.

Jungner H., Sonninen E. 2004. Radiocarbon Dates VI. University of Helsinki. Helsinki.

Kosmenko M. G., Kochkurkina S. I. (eds.) 1996. Arkheologiya Karelii. Karel'iskiy nauchniy tsentr. Petrozavodsk. (in Russian)

Kriiska A., Lang V. 2001. Eesti esiajaloo periodiseering ja kronoloogia. Estonian Journal of Archaeology 5(2): 83109.

Larsson Å. 2009. Breaking and Making Bodies and Pots: Material and Ritual Practices in Sweden in the Third Millennium BC. Aun 40. University of Uppsala. Uppsala.

Lavento M. 2012. Cultivation among hunter-gatherers in Finland: Evidence of activated connections? In R. Grünthal, P. Kallio (eds.), A Linguistic Map of Prehistoric Northern Europe. Mémoires de la Société Finno-Ougrienne 266. Société Finno-Ougrienne. Helsinki: 1-40.
Leskinen S., Personen P. 2008. Vantaan esihistoria. Vantaan kaupunki. Vantaa.

Luho V. 1957. Frühe Kammkeramik. In C. F. Meinander (ed.), Studia Neolithica in honorem Aarne Äyräpää. Suomen Muinaismuistoyhdistyksen Aikakauskirja 58. The Finnish Antiquarian Society. Helsinki: 141-159.

Mökkönen T. 2011. Studies on Stone Age Housepits in Fennoscandia (4000-2000 cal BC): Changes in Ground Plan, Site Location and Degree of Sedentism. Author's edition. Helsinki.

Nordqvist K. 2013. Periodizatsiya neolita-bronzogo veka v Severo-Vostochnoy Evrope/Of the periodization of Eneolithic-Bronze Age in north-east Europe. In V. S. Bochkarev, A. I. Murashkin (eds.), Problemy periodizatsii i khronologii $v$ arkheologii epokhi rannego metalla Vostochnoy Evropy. Sankt-Peterburg gosudarstvenniy universitet. Sankt-Peterburg: 188-199. (in Russian)

2015. Neolithicheskaya keramika Finlyandii: Voprosy khronologii, rasprostraneniya i terminologii. Tverskoy arkheologicheskiy sbornik 10: 249-265. (in Russian)

2016. From separation to interaction: Corded Ware in the eastern Gulf of Finland. Acta Archaeologica 87(1): 49-84.

Nordqvist K., Mökkönen T. 2015a. Äyräpää's Typical Comb Ware: an Umbrella term for the early $4^{\text {th }}$ millennium BC pottery in northeastern Europe? Fennoscandia Archaeologica XXXII: 151-159.

2015b. Pereosmyslenie tipichnoy grebenchatoy keramiki po A. Äyräpää. In G. A. Khlopachev (ed.), Drevnie kul'tury Vostochnoy Evropy: Etalonnye pamyatniki $i$ opornye kompleksy $v$ kontekste sovremennykh arkheologicheskikh issledovaniy. Zamyatinskiy sbornik 4. Muzey antropologii i etnografii im. Petra Velikogo. Sankt-Peterburg: 207-217. (in Russian)

2016. New radiocarbon dates for early pottery in northeastern Europe. In 0. V. Lozovskaya, A. N. Mazurkevich and E. V. Dolbunova (eds.), Traditsii $i$ innovatsiii $v$ izuchenii drevneyshey keramiki. Materialy mezhdunarodnoy nauchnoy konferentsii 24-27 maya 2016 goda, Sankt-Peterburg, Rossiya. Institut istorii materialnoy kul'tury, Gosudarstvenniy Ermitazh, Samarskii gosudarstvenniy sotsial'no-pedagogicheskiy universitet. Sankt-Peterburg: 204-214.

2017a. Novye dannye po arkheologicheskoy khronologii Severo-Zapada Rossii: AMS datirovki neolita-eneolita Karelii. Tverskoy arkheologicheskiy sbornik 11: in press. (in Russian) 
2017b. Keramika tipa Kierikki: Datirovka i paralleli v severo-vostochnoy Evrope. Tverskoy arkheologicheskiy sbornik 11: in press. (in Russian)

Oinonen M., Pesonen P., Alenius T., Heyd V., HolmqvistSaukkonen E., Kivimäki S., Nygrén T., Sundell T. and Onkamo P. 2014. Event reconstruction through Bayesian chronology: Massive mid-Holocene lake-burst triggered largescale ecological and cultural change. The Holocene 24 (11): 1419-1427.

Pälsi S. 1915. Riukjärven ja Piiskunsalmen kivikautiset asuinpaikat Kaukolassa. Helsinki.

Pesonen P. 1996. Early Asbestos Ware. In T. Kirkinen (ed.), Pithouses and Potmakers: Reports of the Ancient Lake Saimaa Project. Helsinki Papers in Archaeology 9. University of Helsinki. Helsinki: 9-39.

2004. Neolithic pots and ceramic chronology: AMS-datings of Middle and Late Neolithic ceramics in Finland. In P. Uino (ed.), Fenno-ugri et Slavi 2002: Dating and Chronology. Museoviraston arkeologian osaston julkaisuja 10. National Board of Antiquities. Helsinki: 87-97.

Pesonen P., Leskinen S. 2011. Pottery of the Stone Age hunter-gatherers in Finland. In P. Jordan, M. Zvelebil (eds.), Ceramics before Farming: the Dispersal of Pottery among Prehistoric Eurasian Hunter-Gatherers. Left Coast Press. Walnut Creek: 299-318.

Pesonen P., Oinonen M., Carpelan C. and Onkamo P. 2012. Early Subneolithic ceramic sequences in eastern Fennoscandia: a Bayesian approach. Radiocarbon 54(3-4): 661676.

Piezonka H. 2015. Jäger, Fischer, Töpfer: Wildbeutergruppen mit früher Keramik in Nordosteuropa im 6. und 5. Jahrtausend v. Chr. Archäeologie in Eurasien 30. Habelt. Bonn.

Rankama T. 1982. Tyylivaihe I:2 Kymenlaaksossa. In H. Edgren, P. Uino (eds.), Studia minora: Professori emerito Carolo Fredrico Meinander die Caroli MCMLXXXII gratia dedicaverunt discipuli. Helsingin yliopiston arkeologian laitos, moniste 29. University of Helsinki. Helsinki: $13-24$.

Reimer P. J. and 25 co-authors. 2013. IntCal13 and marine13 radiocarbon age calibration curves $0-50,000$ years cal BP. Radiocarbon 55(4): 1869-1887.
Seitsonen 0., Nordqvist K., Gerasimov D. V. and Lisitsyn S. N. 2012. 'The good, the bad, the weird': Stone Age and Early Metal Period radiocarbon dates and chronology from the Karelian Isthmus, north-west Russia. Geochronometria 39(2): 101-121.

Siiriäinen A. 1974. Studies Relating to Shore Displacement and Stone Age Chronology in Finland. University of Helsinki. Helsinki.

Skandfer M. 2005. Early, northern Comb Ware in Finnmark: the Concept of Säräisniemi I reconsidered. Fennoscandia Archaeologica XXII: 3-23.

2011. 'All change?' Exploring the role of technological choice in the Early Northern Comb Ware of Finnmark, Arctic Norway. In P. Jordan, M. Zvelebil (eds.), Ceramics before Farming: the Dispersal of Pottery among Prehistoric Eurasian Hunter-Gatherers. Left Coast Press. Walnut Creek: 347-373.

Tarasov A., Nordqvist K., Mökkönen T. and Khoroshun T. 2017. Radiocarbon chronology of the Neolithic-Eneolithic period in the Karelian Republic (Russia). Documenta Praehistorica 44: 98-121.

Torvinen M. 2000. Säräisniemi I Ware. Fennoscandia Archaeologica XVII: 3-35.

2004. The chronological position of Sär I Ware in the Neolithic milieu. In P. Uino (ed.), Fenno-ugri et Slavi 2002: Dating and Chronology. Museoviraston arkeologian osaston julkaisuja 10. National Board of Antiquities. Helsinki: 128-138.

Vanhanen S., Pesonen P. 2016. Wild plant gathering in Stone Age Finland. Quaternary International 404 A: 4355 .

Vikkula, A. 1981. Vantaan Maarinkunnas-Stenkulla: tutkimuksia Uskela-keramiikan alalta. Helsingin yliopiston arkeologian laitos, moniste 27. University of Helsinki. Helsinki.

Vitenkova I. F. 2002. Pamyatniki pozdnego neolita na territorii Karelii. Karel'skiy nauchniy tsentr. Petrozavodsk. (in Russian)

Zhul'nikov A. M. 1999. Eneolit Karelii. Karel'skiy nauchniy tsentr. Petrozavodsk. (in Russian) 


\section{Appendix 1}

List of EN and early MN datings of charred residues/birch bark tars on pottery shards from mainland Finland (Hel and Hela datings are excluded). KM - the National Museum of Finland.

\begin{tabular}{|c|c|c|c|c|c|c|c|c|c|c|c|c|c|c|c|c|c|}
\hline 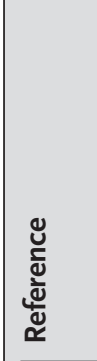 & 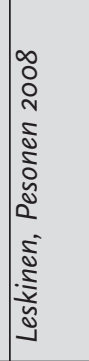 & 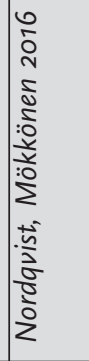 & 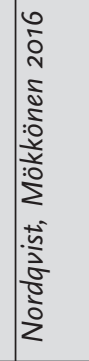 & 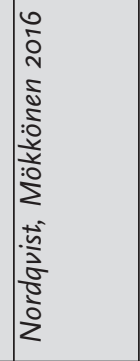 & 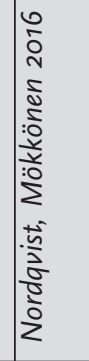 & 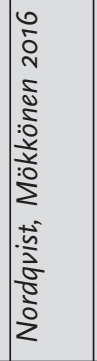 & 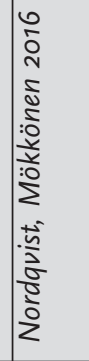 & 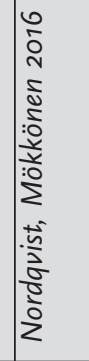 & 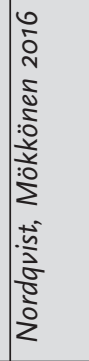 & 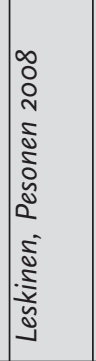 & 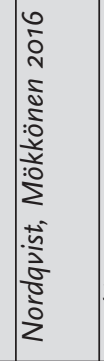 & 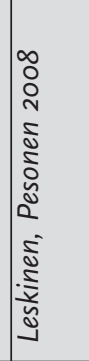 & 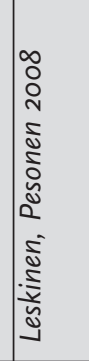 & 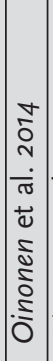 & 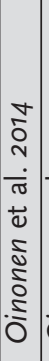 & 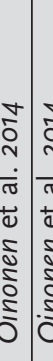 & $\begin{array}{l}\overline{0} \\
0 \\
0\end{array}$ \\
\hline 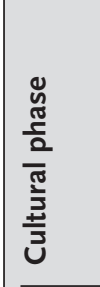 & 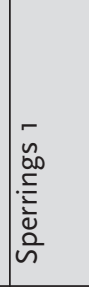 & 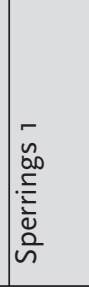 & 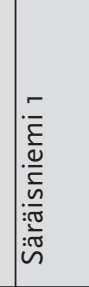 & 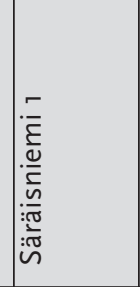 & 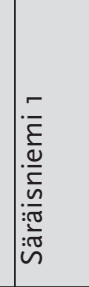 & 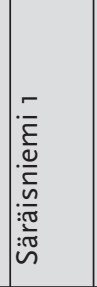 & 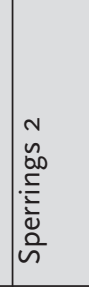 & 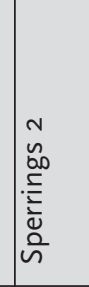 & 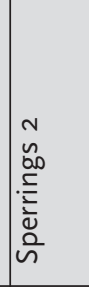 & 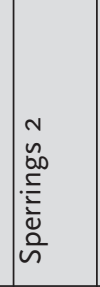 & 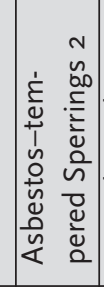 & 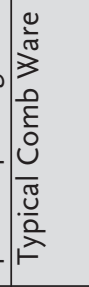 & 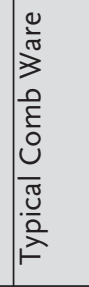 & 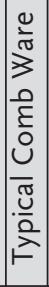 & $\frac{\pi}{3}$ & & \\
\hline 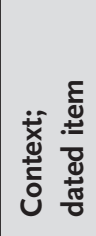 & 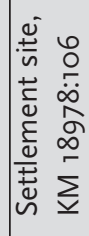 & 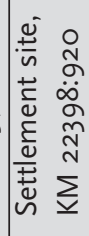 & 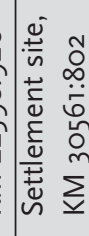 & 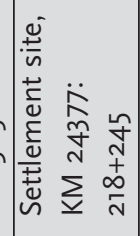 & 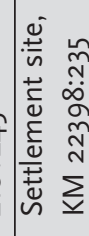 & 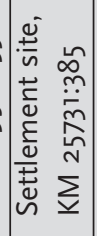 & 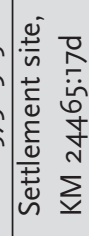 & 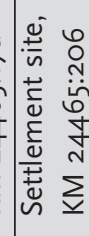 & 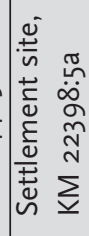 & 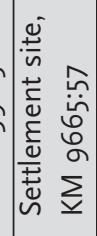 & 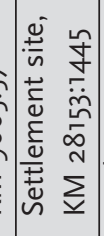 & 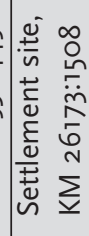 & 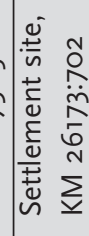 & 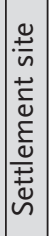 & $\frac{ \pm}{n}$ & $\stackrel{ \pm}{ \pm}$ & \\
\hline$\dot{v}$ & 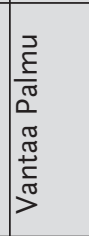 & 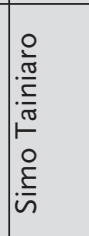 & 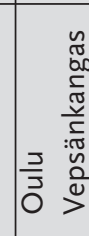 & 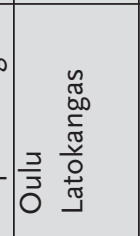 & 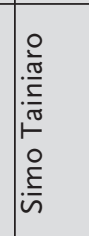 & 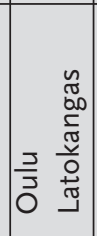 & 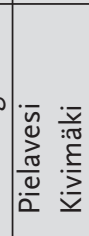 & 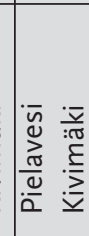 & 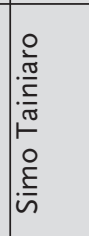 & 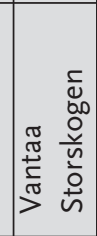 & 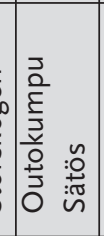 & 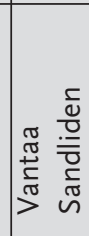 & 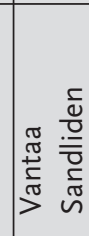 & $\frac{\pi}{\lambda}$ & & - & \\
\hline$\frac{m}{v e}$ & 1 & 1 . & \begin{tabular}{l}
$\infty$ \\
\multirow{2}{0}{} \\
$\stackrel{0}{0}$ \\
1
\end{tabular} & б. & 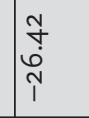 & 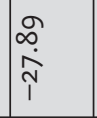 & 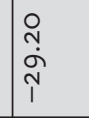 & $\mid \begin{array}{r}\sqrt{2} \\
\underbrace{\prime}\end{array}$ & $\begin{array}{l}5 \\
5 \\
5 \\
\mathfrak{5}\end{array}$ & I & b. & 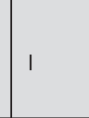 & & 1 & 1 & \begin{tabular}{l|l}
1 & 1
\end{tabular} & \\
\hline 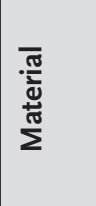 & $\frac{\tilde{n}}{\tilde{u}}$ & t⿹ & 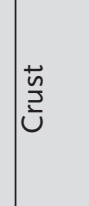 & $\mid \bar{v}$ & $\mid \begin{array}{l}\vec{n} \\
\end{array}$ & $\mid \bar{v}$ & $\stackrel{\vec{n}}{\vec{v}}$ & 䒚 & $\mid \vec{v}$ & 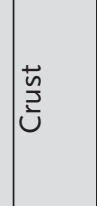 & 鸏 & $\mid \frac{\vec{n}}{\tilde{v}}$ & 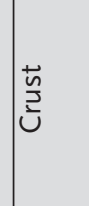 & 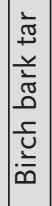 & & & \\
\hline 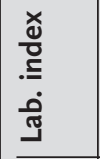 & 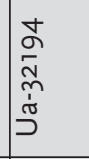 & 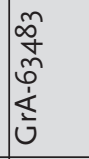 & 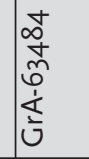 & 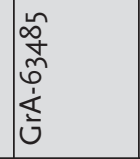 & 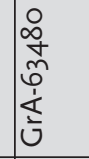 & 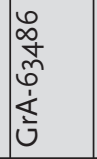 & 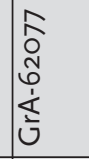 & 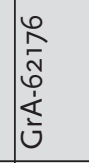 & 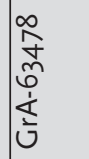 & 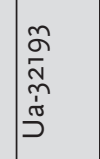 & 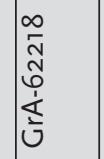 & 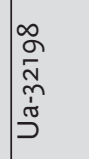 & $\begin{array}{l}\hat{\sigma} \\
\tilde{N} \\
\tilde{N} \\
\tilde{\omega}\end{array}$ & $\begin{array}{l}\mathcal{N} \\
\mathbf{N} \\
0 \\
\tilde{N} \\
\tilde{N} \\
0\end{array}$ & 怘 & & \\
\hline 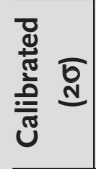 & 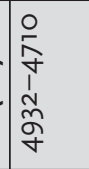 & 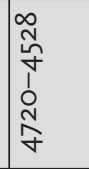 & 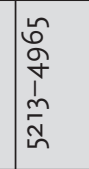 & $\begin{array}{l}0 \\
2 \\
\hat{\gamma} \\
1 \\
0 \\
0 \\
0 \\
0 \\
i n\end{array}$ & 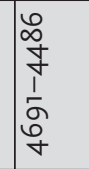 & 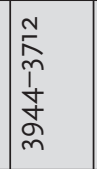 & 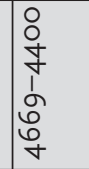 & 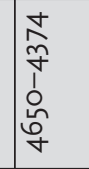 & 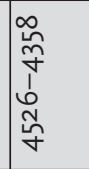 & 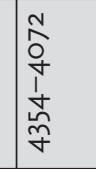 & $\begin{array}{l}\infty \\
0 \\
0 \\
\tilde{n} \\
\frac{1}{q}\end{array}$ & $\begin{array}{l}0 \\
0 \\
0 \\
0 \\
1 \\
0 \\
\infty\end{array}$ & $\begin{array}{l}0 \\
\tilde{n} \\
\hat{n} \\
\swarrow \\
\vdots \\
m\end{array}$ & $\mid \begin{array}{l}\tilde{\tilde{N}} \\
\hat{\tilde{n}} \\
\tilde{\tilde{\omega}}\end{array}$ & & & \\
\hline 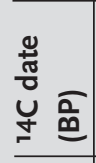 & 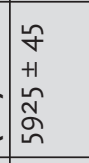 & 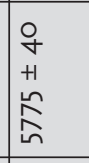 & $\begin{array}{l}q \\
q \\
+1 \\
0 \\
\tilde{\omega} \\
\tilde{\sigma}\end{array}$ & \begin{tabular}{|l} 
\\
\\
+1 \\
0 \\
0 \\
\\
\end{tabular} & $\begin{array}{l}0 \\
0 \\
+ \\
+1 \\
\tilde{N} \\
\tilde{n} \\
\tilde{n}\end{array}$ & 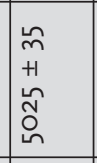 & $\begin{array}{l}q \\
+ \\
+1 \\
0 \\
0\end{array}$ & $\begin{array}{l}0 \\
+ \\
+1 \\
+1 \\
\hat{n} \\
\hat{0} \\
\text { in }\end{array}$ & + & $\begin{array}{l}\stackrel{u}{y} \\
+1 \\
\stackrel{n}{n}\end{array}$ & $\mid \begin{array}{l}\tilde{m} \\
+1 \\
0 \\
0\end{array}$ & \begin{tabular}{|l|}
$\mathfrak{q}$ \\
+1 \\
$o$ \\
$o$ \\
$o$ \\
$\gamma$ \\
\end{tabular} & 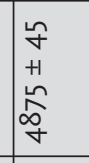 & $\begin{array}{l}\stackrel{\sim}{m} \\
+1 \\
+1 \\
\dot{q}\end{array}$ & $\begin{array}{l}o \\
q \\
+\end{array}$ & & I \\
\hline$\frac{c}{2}$ & $I_{-}$ & N & $m$ & t & in & 6| & $\wedge$ & $\left.\right|_{\infty}$ & $\sigma$ & - & $=$ & $1:$ & $m$ & & & & $=\alpha$ \\
\hline
\end{tabular}

